\title{
Baseline survey of herbicide resistance in Russian thistle (Salsola tragus L.) finds no resistance in Manitoba
}

\author{
Charles M. Geddes, Robert H. Gulden, Tammy Jones, Julia Y. Leeson, Mattea M. Pittman, \\ Shaun M. Sharpe, Scott W. Shirriff, and Hugh J. Beckie
}

\begin{abstract}
Recent confirmations of glyphosate-resistant Russian thistle (Salsola tragus L.) in Montana, Washington, and Oregon, warrant greater surveillance of herbicide-resistant Russian thistle in western Canada. A randomized-stratified survey of 315 sites in Manitoba was conducted in 2018 to determine the incidence of herbicide resistance in Russian thistle and other weeds sampled post-harvest. Russian thistle populations were collected from 14 of the 315 sites surveyed. None of these populations exhibited resistance to acetolactate synthase inhibitors (tribenuron/thifensulfuron), synthetic auxins (2,4-D ester or fluroxypyr), or glyphosate. This Manitoba survey of herbicide-resistant Russian thistle serves as a baseline for future surveillance efforts.
\end{abstract}

Key words: acetolactate synthase inhibitor, glyphosate, herbicide resistance, survey, synthetic auxin.

Résumé : La confirmation récente de plants de soude roulante (Salsola tragus L.) résistants au glyphosate dans les états du Montana, de Washington et de l'Oregon justifie qu'on suive mieux cette plante résistante à l'herbicide dans l'ouest Canadien. En 2018, les auteurs ont procédé à une étude randomisée avec stratification sur 315 sites du Manitoba en vue de préciser l'incidence de la résistance aux herbicides chez la soude roulante et d'autres adventices après la récolte. De la soude roulante a été recueillie dans 14 des 315 sites examinés. Aucun peuplement ne résistait aux inhibiteurs de l'acétolactate synthase (tribenuron/thifensulfuron), aux auxines synthétiques (2,4-D ester ou fluroxypyr) ni au glyphosate. Cette étude sur la soude roulante résistante aux herbicides réalisée au Manitoba servira de point de comparaison lors des travaux subséquents de surveillance. [Traduit par la Rédaction]

Mots-clés : inhibiteur de l'acétolactate synthase, glyphosate, résistance aux herbicides, enquête, auxine synthétique.

\section{Introduction}

Russian thistle (Salsola tragus L.) is an early emerging $\mathrm{C}_{4}$ summer-annual tumbleweed that tolerates heat, drought and salinity, and competes well with crops in the semi-arid region of the Canadian prairies (Beckie and Francis 2009). It is the $9^{\text {th }}$ most abundant weed after post-emergence herbicide application in the mixed grassland ecoregion of Saskatchewan, and is most abundant in durum and lentil, followed by oat, pea, mustard and barley (Leeson 2016). While this weed is more abundant in the dry southern regions of Alberta and Saskatchewan, it can be problematic also in western Manitoba where a 2016 survey of annual crops characterized Russian thistle as the $19^{\text {th }}$ most abundant weed

Received 18 September 2020. Accepted 23 March 2021.

C.M. Geddes* and M.M. Pittman. Agriculture and Agri-Food Canada, Lethbridge Research and Development Centre, 54031 st Avenue South, Lethbridge, AB T1J 4B1, Canada.

R.H. Gulden. University of Manitoba, Department of Plant Science, 66 Dafoe Road, Winnipeg, MB R3T 2N2, Canada.

T. Jones. Manitoba Agriculture and Resource Development, 65 3rd Avenue Northeast, Carman, MB R0G 0J0, Canada.

J.Y. Leeson, S.M. Sharpe, S.W. Shirriff, and H.J. Beckie. ${ }^{\dagger}$ Agriculture and Agri-Food Canada, Saskatoon Research and Development Centre, 107 Science Place, Saskatoon, SK S7N 0X2, Canada.

Corresponding author: Charles M. Geddes (email: Charles.Geddes@canada.ca).

${ }^{*}$ C.M. Geddes served as an Associate Editor at the time of manuscript review and acceptance; peer review and editorial decisions regarding this manuscript were handled by $S$. White.

${ }^{\dagger}$ Present address: Australian Herbicide Resistance Initiative, School of Agriculture and Environment, University of Western Australia, Perth, WA 6009, Australia.

(C) 2021 Authors R. Gulden and T. Jones, and Her Majesty the Queen in Right of Canada as represented by the Minister of Agriculture and Agri-Food. This work is licensed under a Creative Commons Attribution 4.0 International License (CC BY 4.0), which permits unrestricted use, distribution, and reproduction in any medium, provided the original author(s) and source are credited. 
species in the rural municipalities of North Cypress and Langford and $23^{\text {rd }}$ most abundant weed species in Oakland and South Cypress (Leeson 2016; Leeson et al. 2017a, 2017b). Russian thistle interference in wheat can result in over 50\% yield loss (Beckie and Francis 2009).

In the Canadian prairies, Russian thistle abundance has decreased over the past half-century despite increased incidence of resistance to acetolactate synthase (ALS)inhibiting herbicides (Leeson 2016; Leeson et al. 2017a, 2017b; Beckie et al. 2019a). A 2017 survey of Alberta documented ALS inhibitor resistance in $62 \%$ of the Russian thistle populations sampled, which was a marked increase from previous estimates (Beckie et al. 2019a). Similar surveys of Manitoba and Saskatchewan have not been conducted. Pulses and other crops which rely on ALSinhibiting herbicides for weed control risk infestation of ALS inhibitor-resistant Russian thistle biotypes.

Recent confirmations of glyphosate-resistant Russian thistle in Montana, Washington, and Oregon (Barroso 2017; Kumar et al. 2017) call for increased surveillance of herbicide-resistant Russian thistle in western Canada. Grower submission of Russian thistle samples from Alberta with suspected resistance to ALS inhibitors, glyphosate and synthetic auxins warrants further testing of survey samples with these modes of action (CM Geddes, unpublished observation).

The current status of herbicide-resistant Russian thistle in Manitoba is unknown, and increased surveillance is required to understand the current distribution of these biotypes. Spread of herbicide-resistant Russian thistle via wind-driven tumbleweeds and pollenmediated gene flow (Beckie and Francis 2009) may introduce these biotypes to Manitoba from western provinces or US states. A baseline survey of Manitoba was conducted to document the incidence of herbicide resistance in Russian thistle, and the impact of these biotypes on Manitoba crop production.

\section{Materials and Methods}

Russian thistle samples were collected during a randomized survey of 315 sites covering 46 rural municipalities in Manitoba in October 2018. Survey sites were stratified proportional to the cultivated area within each ecodistrict (area of similar landform, soil, vegetation, and land use within each ecoregion). Sites were predetermined randomly at the township scale, and included both agricultural fields and ruderal areas (roadsides/ ditches, railway rights-of-way, and oil well sites). The sites were visited post-harvest during a three-week period in early October to ensure that mature seeds were collected for resistance testing. When present at the site, 10-20 mature Russian thistle plants were collected and composited, resulting in a sample representing one population. The GPS location of each weed population was recorded and used to develop a map of sample sites using QGIS 3.12 (QGIS Geographic Information System, Open Source Geospatial Foundation).
Fig. 1. Locations of the 14 Russian thistle populations sampled and tested for resistance in a 2018 survey of Manitoba (QGIS 3.12, QGIS Geographic Information System, Open Source Geospatial Foundation). [Colour online.]

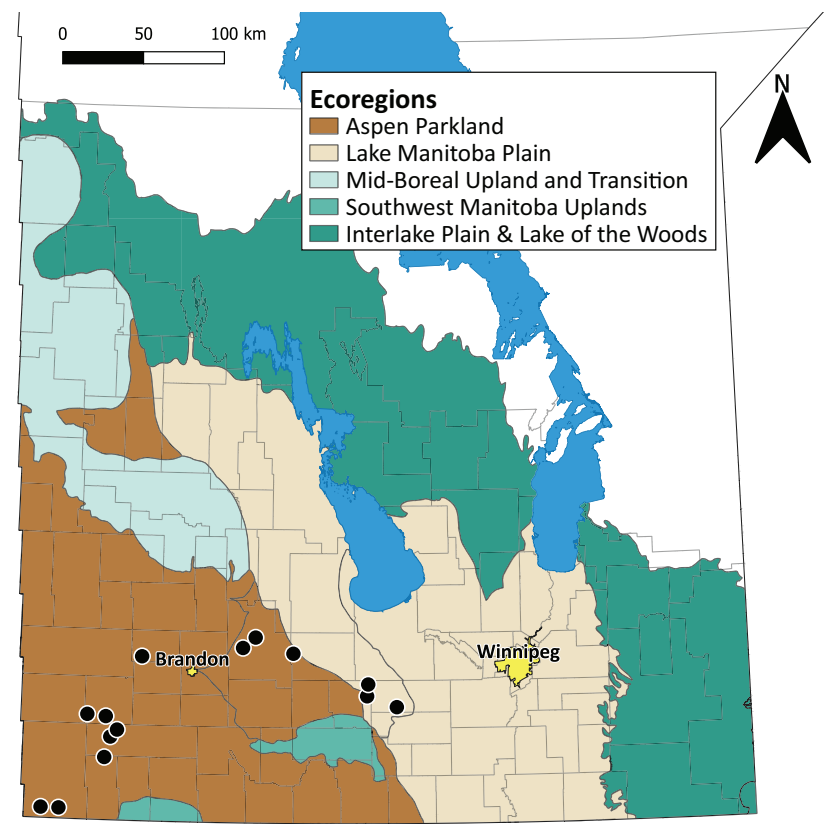

Samples were air-dried at room temperature and threshed under contained conditions at Agriculture and Agri-Food Canada (AAFC) in Saskatoon, SK, and the University of Manitoba in Winnipeg, MB. The samples were screened for herbicide resistance in the greenhouse at AAFC in Lethbridge, $\mathrm{AB}$, following the procedures outlined by Beckie et al. (2019a). Seeds from each population were planted in $52 \mathrm{~cm} \times 26 \mathrm{~cm} \times 5 \mathrm{~cm}$ flats containing modified Cornell soilless potting mixture (Sheldrake and Boodley 1966) with $756 \mathrm{mg}$ nitrogen (N), $958 \mathrm{mg}$ phosphorus $(\mathrm{P})$, and $505 \mathrm{mg}$ potassium $(\mathrm{K}) \cdot \mathrm{L}^{-1}$ mixture. A minimum of 100 seedlings from each population (3 flats or replicates per population per run) were treated separately with tribenuron/thifensulfuron (Refine ${ }^{\circledR}$ SG, FMC Corporation), glyphosate (Roundup WeatherMax ${ }^{\circledR}$, Bayer CropScience), 2,4-D ester (2,4-D ester 700, Nufarm Agriculture), and fluroxypyr (Prestige ${ }^{\mathrm{TM}} \mathrm{XCA}$, Corteva Agriscience) at discriminating doses of $15(5+10), 900,920$, and 140 g a.i./a.e. ha $^{-1}$, respectively, at $3-5 \mathrm{~cm}$ plant height. Herbicides were applied using a controlled-environment moving-nozzle cabinet sprayer equipped with a flat-fan TeeJet ${ }^{\circledR}$ 8002VS nozzle (Spraying Systems Co., Wheaton, IL) delivering $200 \mathrm{~L} \cdot \mathrm{ha}^{-1}$ spray solution at $275 \mathrm{kPa}$ and a speed of $2.4 \mathrm{~km} \cdot \mathrm{ha}^{-1}$ in a single pass $50 \mathrm{~cm}$ above the foliage. The experiment followed a completely randomized design, and environmental conditions in the greenhouse included a $16 \mathrm{hr}$ photoperiod supplemented with $100 \mu \mathrm{mol} \cdot \mathrm{m}^{-2} \cdot \mathrm{s}^{-1}$ light, and $20^{\circ} \mathrm{C} / 18^{\circ} \mathrm{C}$ day/night temperature. The trays were watered to field capacity daily. The experiment was conducted two times. 
Fig. 2. Frequency (\%) of fields in which Russian thistle was found in Manitoba surveys of annual crops taking place during the 1970s (1978-1981), 1986, 1997, 2002, and 2016 [Modified from Leeson et al. (2017a)]. [Colour online.]

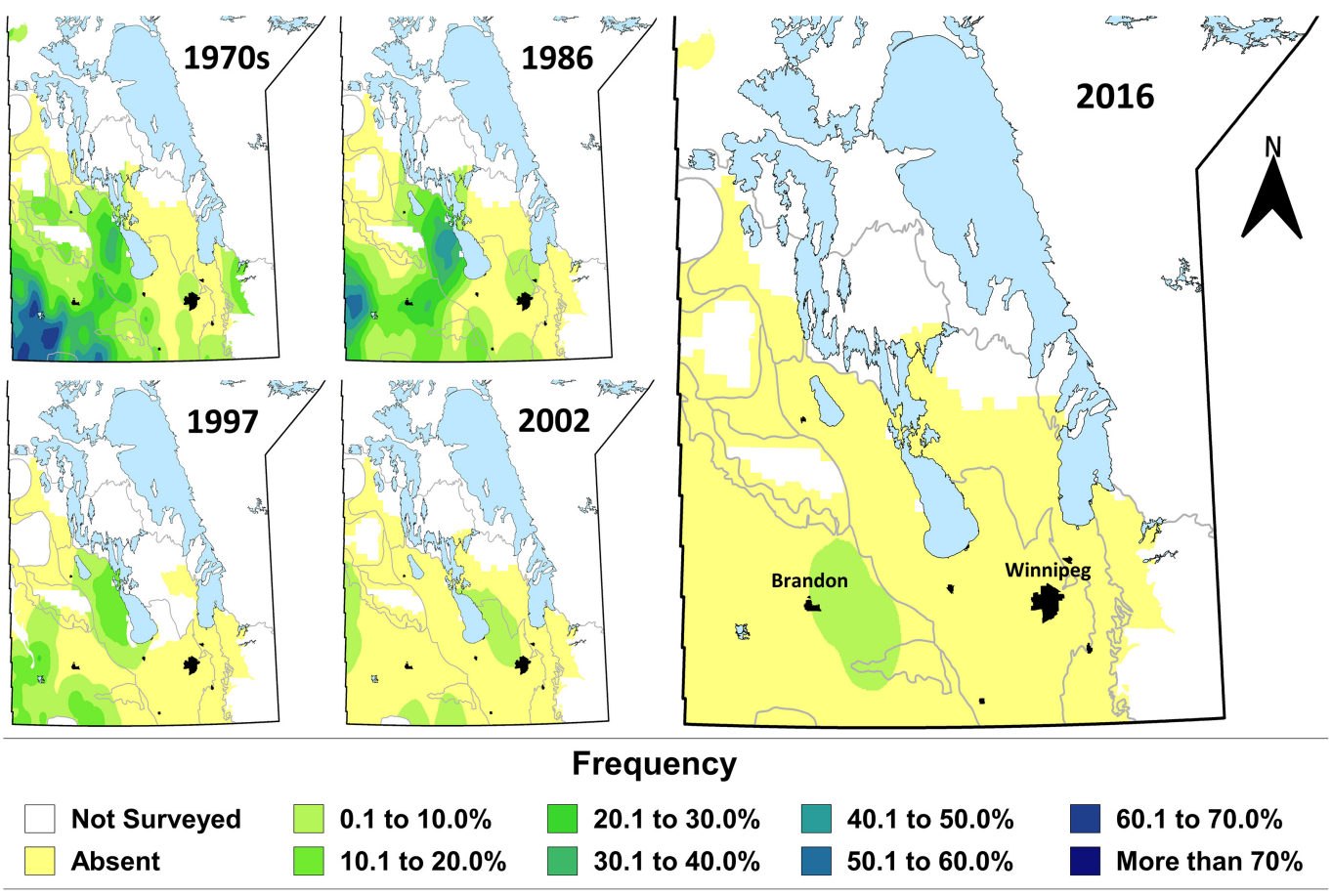

At three weeks after treatment, individual plants in each tray were rated as susceptible (dead or nearly dead) or resistant (some injury but new growth, or no injury) by comparing with herbicide-treated and untreated resistant and susceptible control populations, where available [as described by Beckie et al. (2019a)]. The frequency of herbicide-resistant individuals was determined as a percentage of the number of treated individuals in each experimental unit (tray).

\section{Results and Discussion}

Russian thistle was found at only 14 of the 315 surveyed sites in Manitoba, including the rural municipalities of Arthur, Cameron, Daly, Edward, Grey, North Cypress, North Norfolk, Sifton, and South Norfolk (Fig. 1). All of the populations were found in agricultural fields; eight following harvest of small grain cereals, two following canola, two following soybean, one following corn, and one following potato.

All of the Russian thistle populations were determined to be susceptible to ALS inhibitors (tribenuron/ thifensulfuron), synthetic auxins (2,4-D ester and fluroxypyr), and glyphosate. No Russian thistle plants survived the herbicide treatments. Herbicide-resistant Russian thistle has not been identified in Manitoba, even though ALS inhibitor-resistant biotypes have been present in Saskatchewan since 1989 (Morrison and Devine 1994).

In mid-season surveys of annual crops in Manitoba, the frequency of fields in which Russian thistle was found has declined since the 1970s (Fig. 2), and was lower in Manitoba compared with Saskatchewan or Alberta (Leeson 2016; Leeson et al. 2017a, 2017b). Decreased frequency and abundance of Russian thistle in the Prairie Provinces coincides with the introduction of ALS-inhibiting herbicides in the 1980s (Fig. 2). Rapid increase of ALS inhibitor resistance in Alberta was documented only recently (Beckie et al. 2019a), suggesting that the impact of these biotypes could manifest in future surveys of weed abundance. Weed abundance surveys conducted during the 1970s show the potential range of Russian thistle before effective ALS inhibitors were available on the market (Fig. 2). They show also the potential impact that ALS inhibitor-resistant Russian thistle could have on Manitoba agriculture.

Several biological traits of Russian thistle suggest that the risk of evolving herbicide resistance in this species is greater than many other weed species present in the Canadian prairies. High genetic variability, low seed longevity, high seedbank turnover, high outcrossing, and high plant fecundity (Beckie and Francis 2009) all contribute positively to resistance selection pressure. These traits are observed also in kochia [Bassia scoparia (L.) A.J. Scott], a species with unprecedented increase of herbicide resistance in western Canada (Beckie et al. 2019b; Geddes et al. 2021). Over the course of two decades, ALS inhibitor resistance in kochia increased from the first confirmations to nearly all kochia populations in western Canada (Beckie et al. 2019b). Similarly, glyphosate resistance in kochia increased from $4 \%$ to $50 \%$ of populations sampled in Alberta between 2012 and 2017 
(Beckie et al. 2019b), and $1 \%$ to $58 \%$ of populations sampled in Manitoba between 2013 and 2018 (Geddes et al. 2021). Recent documentation of ALS inhibitor resistance in $62 \%$ of Russian thistle populations sampled in Alberta (in 2017) suggests that resistance can spread rapidly among Russian thistle populations, similar to that observed for kochia (Beckie et al. 2019a). Unlike kochia, however, ALS inhibitor-resistant Russian thistle remains undocumented in Manitoba, suggesting that possible geographic, climatic or agronomic barriers could be mitigating the spread of this biotype into Manitoba production systems.

The current survey suggests that herbicide-resistant Russian thistle is likely not present in Manitoba, or is present at an abundance below the survey detection threshold given the relatively small sample size. This is good news for growers in Manitoba because chemical tools to manage Russian thistle remain effective in these regions. Even though herbicide-resistant Russian thistle was not detected in the current survey, growers and agronomists should remain diligent and pay close attention to how this weed responds to herbicide applications in the field. Rapid spread of ALS inhibitor-resistant Russian thistle in Alberta demonstrates the critical importance of early detection and rapid response to these resistant weed biotypes. The probability of finding a novel herbicide-resistant weed increases when the biotype is discovered in neighboring provinces or states. Greater surveillance of herbicide-resistant Russian thistle is warranted moving forward to aid in early detection of resistant biotypes in western Canada. Of particular concern is resistance to the commonly used herbicide glyphosate, and the risk of this biotype spreading from neighboring states.

\section{Acknowledgements}

The authors thank the Alberta Wheat Commission, Manitoba Pulse and Soybean Growers, Manitoba Crop Alliance, Saskatchewan Canola Development Commission, Saskatchewan Pulse Crop Development Board, and Western Grains Research Foundation for their generous support in funding this research. This research was funded through Agriculture and Agri-Food Canada project J-001934. The authors thank Kasey Dunn for the development of Fig. 1.

\section{References}

Barroso, J. 2017. Identification of glyphosate resistance in Russian thistle in northeastern Oregon. Crops Soils Mag. 50: 26-28. doi:10.2134/cs2017.50.0211.

Beckie, H.J., and Francis, A. 2009. The biology of Canadian weeds. 65. Salsola tragus L. (updated). Can. J. Plant Sci. 89: 775-789. doi:10.4141/CJPS08181.

Beckie, H.J., Hall, L.M., Shirriff, S.W., Martin, E., and Leeson, J.Y. 2019a. Glyphosate and acetolactate synthase inhibitor resistance in Russian thistle (Salsola tragus L.) in Alberta. Can. J. Plant Sci. 99: 384-387. doi:10.1139/cjps-2018-0252.

Beckie, H.J., Hall, L.M., Shirriff, S.W., Martin, E., and Leeson, J.Y. 2019b. Triple-resistant kochia [Kochia scoparia (L.) Schrad.] in Alberta. Can. J. Plant Sci. 99: 281-285. doi:10.1139/cjps-20180256.

Geddes, C.M., Pittman, M.M., Gulden, R.H., Jones, T., Leeson, J.Y., Sharpe, S.M., et al. 2021. Rapid increase in glyphosate resistance and confirmation of dicamba-resistant kochia (Bassia scoparia) in Manitoba. Can. J. Plant Sci. [In press]. doi:10.1139/ cjps-2021-0169.

Kumar, V., Spring, J.F., Jha, P., Lyon, D.J., and Burke, I.C. 2017. Glyphosate-resistant Russian-thistle (Salsola tragus) identified in Montana and Washington. Weed Technol. 31: 238-251. doi:10.1017/wet.2016.32.

Leeson, J.Y. 2016. Saskatchewan weed survey of cereal, oilseed and pulse crops in 2014 and 2015. Weed Survey Series Publication 16-1, Agriculture and Agri-Food Canada, Saskatoon, SK. 256 pp.

Leeson, J.Y., Gaultier, J., and Grenkow, L. 2017a. Manitoba weed survey of annual crops in 2016. Weed Survey Series Publication. 17-2. Agriculture and Agri-Food Canada, Saskatoon, SK. 203 pp.

Leeson, J.Y., Hall, L.M., and Neeser, C. 2017b. Residual weed population shifts in Alberta - 1973 to 2017. Proc. 71st Canadian Weed Science Society Annual Meeting, 20-23 Nov. 2017, Saskatoon, SK. pp 39-40. CWSS-SCM. [Online]. Available from https://weedscience.ca/resources/annual-meeting-archivedfiles/.

Morrison, I.N., and Devine, M.D. 1994. Herbicide resistance in the Canadian prairie provinces: Five years after the fact. Phytoprot. 75: 5-16. doi:10.7202/706067ar.

Sheldrake, R., Jr., and Boodley, J.W. 1966. Plant growing in lightweight artificial mixes. Acta Hortic. 4: 155-157. doi:10.17660/ ActaHortic.1966.4.32. 